\title{
Validation of a UV-spectrophotometric analytical method for determination of LPSF/AC04 from inclusion complex and liposomes
}

\author{
Rafaela Siqueira Ferraz ${ }^{1}$, Elisângela Afonso Moura Mendonça ${ }^{2}$, Jéssica Priscila Avelino Silva ${ }^{1}$, \\ Isabella Macário Ferro Cavalcanti, ${ }^{1,3}$, Mariane Cajubá Britto Lira-Nogueira ${ }^{13^{*}}$, Suely Lins \\ Galdino $^{4, \dagger}$, Ivan Rocha Pitta ${ }^{4}$, Maria do Carmo Alves Lima ${ }^{4}$, Nereide Stela Santos-Magalhães ${ }^{1}$
}

\author{
${ }^{1}$ Universidade Federal de Pernambuco, UFPE, Laboratório de Imunopatologia Keizo-Asami, LIKA, Recife, PE, Brazil, \\ ${ }^{2}$ Universidade Estadual da Paraíba, UEPB, Laboratório de Síntese e Vetorização de Moléculas, João Pessoa, PB, Brazil, \\ ${ }^{3}$ Centro Acadêmico de Vitória, CAV, Recife, PE, Brazil, ${ }^{4}$ Universidade Federal de Pernambuco, UFPE, Laboratório de \\ Planejamento e Síntese de Fármacos, Departamento de Antibióticos, Recife, PE, Brazil
}

\begin{abstract}
The aim of this study was to develop and validate a UV spectrophotometric method for determination of LPSF/AC04 from inclusion complex and encapsulated into liposomes. The validation parameters were determined according to the International Conference on Harmonisation (ICH) and National Health Surveillance Agency (ANVISA) guidelines. LPSF/AC04 was determined at $250 \mathrm{~nm}$ in methanol by a UV spectrophotometric method, exhibiting linearity in the range from 0.3 to $2 \mu \mathrm{g} \cdot \mathrm{mL}^{-1}$ (Absorbance $=0.18068$ $\left.\mathrm{x}\left[\mathrm{LPSF} / \mathrm{AC} 04 \mu \mathrm{g} \cdot \mathrm{mL}^{-1}\right]+0.00348\right),\left(\mathrm{r}^{2}=0.9995\right)$. The limits of detection and quantification were $0.047 \mu \mathrm{g} . \mathrm{mL}^{-1}$ and $0.143 \mu \mathrm{g} . \mathrm{mL}^{-1}$, respectively. The method was accurate, precise, reproducible and robust since all the samples analyzed had coefficient of variation of less than $5 \%$ and no statistically significant difference between theoretical and practical concentrations was detected. Thus, a rapid, simple, low cost and sensitive spectrophotometric method was developed and validated for determining the content of inclusion complex and liposomes containing LPSF/AC04.
\end{abstract}

Uniterms: UV Spectrophotometry/quantitative analysis/method validation. Acridine derivatives/ determination. Inclusion complex. Liposomes.

O objetivo deste estudo foi desenvolver e validar um método espectrofotométrico para determinação do LPSF/AC04 em complexo de inclusão e encapsulado em lipossomas. Os parâmetros de validação foram determinados de acordo com o International Conference on Harmonisation (ICH) e Agência Nacional de Vigilância Sanitária (ANVISA). OLPSF/AC04 foi determinado a $250 \mathrm{~nm}$ em metanol pelo método espectrofotométrico UV, que apresenta linearidade na faixa de 0,3 a $2 \mu \mathrm{g} / \mathrm{mL}$ (Absorbância $=0,18068 \mathrm{x}$ $[\mathrm{LPSF} / \mathrm{AC} 04 \mu \mathrm{g} / \mathrm{mL}]+0,00348),\left(\mathrm{r}^{2}=0,9995\right)$. Os limites de detecção e quantificação foi $0,047 \mu \mathrm{g} / \mathrm{mL}$ e $0,143 \mu \mathrm{g} / \mathrm{mL}$, respectivamente. O método foi exato, preciso, reprodutível e robusto e todas as amostras analisadas apresentaram coeficiente de variação menor que $5 \%$ e não houve diferença estatisticamente significante entre a concentração teórica e a prática. Assim, um método espectrofotométrico rápido, simples, sensível e de baixo custo foi desenvolvido e validado para determinar o conteúdo do LPSF/ AC04 em complexos de inclusão e encapsulados em lipossomas.

Unitermos: Espectrofotometria UV/análise quantitativa/validação de método. Derivados acridínicos/ determinação. Complexos de inclusão. Lipossomas.

\footnotetext{
*Correspondence: M. C. B. Lira-Nogueira. Centro Acadêmico de Vitória CAV, Universidade Federal de Pernambuco - UFPE. Rua do Alto do Reservatório s/n, Bela Vista, 55608-680 - Vitória de Santo Antão, PE - Brasil. E-mail: marianelira@gmail.com

†in memoriam
} 


\section{INTRODUCTION}

LPSF/AC04 (5Z)-[5-acridine-9-yl-methylene-3(4-methyl-benzyl)-thiazolidine-2,4-dione] (Figure 1A) is an acridinylidene thiazolidinedione, a monoacridinine structural analogue of amsacrine (Figure 1B) (Denny, 2002; Mourão et al., 2005). A variety of different acridine derivatives has been synthesized and promising results obtained in some cases, prompting the development of new acridine-based drugs that present a wide spectrum of biological activities, such as antibacterial, antimalarial, antitrypanosomial (Bonse et al., 1999), antileishmanial and antiviral (Goodell et al., 2006) actions, and most notably antitumor activity (Goodell et al., 2008).
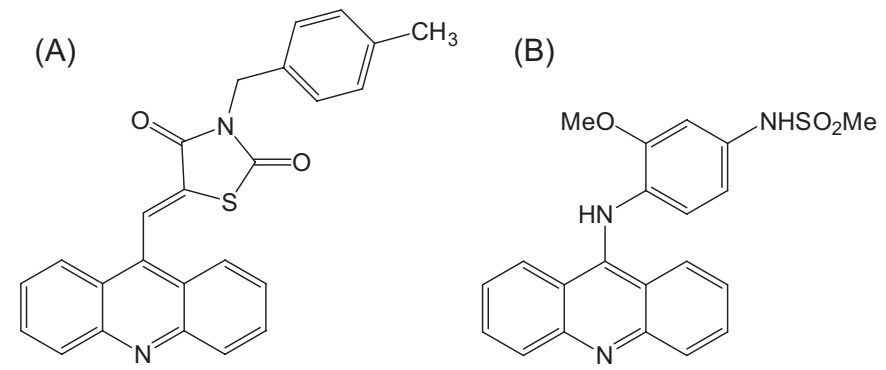

FIGURE 1 - Chemical structures of (5-(acridine-9-ylmethylene)-(4-methyl-benzyl)-thiazolidine-2,4-dione)-LPSF/ AC04 (A) and amsacrine (B).

The rational design of drugs is one of the most useful approaches for the introduction of new drugs in therapy and widely used by researchers in the medicinal chemistry field. In this context, LPSF/AC04 is an acridine-based derivative, part of a series of new anticancer agents synthesized for the purpose of developing more effective and less toxic anticancer drugs. This molecule, with potential antitumor activity, was synthesized at the Laboratory of Rational Design and Synthesis of Drugs (LPSF) of the Federal University of Pernambuco, Brazil. LPSF/AC0 4 has shown antitumor activity with tumor inhibition of more than $85 \%$ in a murine sarcoma 180 model after 8 days of treatment with $100 \mathrm{mg} / \mathrm{kg}$ i.p/day (De Lima, Lins, Pitta, 2007). In addition, a recent study has reported preliminary pharmacokinetics of LPSF/AC04 with a half-life of $66 \mathrm{~h}$ and accumulation in different tissues (Pigatto et al., 2011). However, heterocyclic acridine derivatives such as LPSF/AC04 are characterized by low solubility in aqueous solutions, limiting both clinical trials and its therapeutic use.

In order to minimize this problem, incorporation of the drug into controlled release systems is required. Liposomes are widely used in pharmaceutical applications, such as for drug delivery vehicles of several therapeutic agents, given their versatility and clinical efficacy (Torchilin, 2006). In addition, cyclodextrins are used to improve the solubility of poorly hydrophilic drugs. Cyclodextrins (CyDs) have a relatively nonpolar cylindrical cavity that can bind, and thereby solubilize, a wide range of hydrophobic molecules (Loftsson, Hreinsdóttir, Másson, 2005; Loftsson, Duchêne, 2007). The main purpose of inclusion complex-loaded liposomes is to combine the advantages of cyclodextrins as drug solubility enhancement agents with those of liposomes as drug-targeting agents. Some authors have cited the use of cyclodextrins in the formation of inclusion complexes with hydrophobic drugs, including acridine derivatives, to enhance their solubility (Schuette et al., 1991; Correia et al., 2002; Loftsson, Hreinsdóttir, Másson, 2005; Loftsson, Duchêne, 2007; Mishur et al., 2011; Al Omari et al., 2011).

The quality control of pure drugs and dosage forms are carried out using official and validated methods. Despite the clear advantages of using the HPLC chromatographic technique, the method has several limitations such as the high cost of instrumentation and operation, relatively long analysis times and the need for experience in handling the equipment and in processing samples (Siqueira-Moura et al., 2008). Spectrophotometry is a highly convenient analytical technique that is widely used in laboratories for quality control given its simplicity, low cost and wide availability (Darwish et al., 2009).

The main objective of this work was to develop and validate a simple, precise, accurate and economical analytical method for quantifying LPSF/AC04 by UVspectrophotometry. Subsequently, the resultant method can be applied to determine pure drug and dosage forms, such as liposomes and inclusion complexes containing LPSF/AC04.

\section{MATERIAL AND METHODS}

\section{Apparatus}

A UV spectrophotometer (Ultrospec 3000 Pro, Amersham Pharmacia Biotech, Sweden) equipped with $10 \mathrm{~mm}$ quartz cells was used for all the absorption measurements. A magnetic stirrer (Variomag, Germany), Vibra Cell sonicator (Branson, USA), lyophilizer EZ-DRY (FTS Systems, USA) and thermostatically-controlled water bath (Bioblock Scientific, France) were employed.

\section{Material and reagents}

LPSF/AC04, obtained by the synthetic route 
(Pitta et al., 2007), was kindly provided by the Laboratory of Medicinal Chemistry of the Federal University of Pernambuco, Brazil, CAS:440367-56-6. Cholesterol (CHOL), trehalose, stearylamine (SA) and 2 -hydroxypropyl- $\beta$-cyclodextrin (HP- $\beta$-CyD) were purchased from Sigma-Aldrich (St. Louis, USA); Soybean phosphatidylcholine (SPC, S100 ${ }^{\circledR}$ ) was obtained from Lipoid GmbH (Ludwigshafen, Germany). Methanol and chloroform (Merck, Darmstadt, Germany) were of analytical grade.

\section{LPSF/AC04 standard solutions}

LPSF/AC04 has a molecular weight of 410 and melting point of $199^{\circ} \mathrm{C}$, being characterized as a yellow-greenish amorphous powder. This molecule was characterized by spectroscopy (IR, ${ }^{1} \mathrm{H}-\mathrm{NMR}$, $\mathrm{Ms}), \mathrm{C}_{25} \mathrm{H}_{18} \mathrm{~N}_{2} \mathrm{O}_{2} \mathrm{~S}$ synthetic route has $96 \%$ yield: TLC benzene:ethyl acetate $(9: 1) \mathrm{R}_{\mathrm{f}}: 0.45$. IR cm $\mathrm{cm}^{-1}(\mathrm{KBr}): v 1746$, $1697,1630,1378,1339,1149,758 .{ }^{1} \mathrm{H}$ NMR $(\delta \mathrm{ppm}$, $\left.\mathrm{CDCl}_{3}\right): 2.37\left(\mathrm{~s}, \mathrm{CH}_{3}\right) ; 4.92\left(\mathrm{~s}, \mathrm{CH}_{2}\right) ; 7.21(\mathrm{~d}, 2 \mathrm{H}$ benzyl, $\mathrm{J}=7.8 \mathrm{~Hz}), 7.42(\mathrm{~d}, 2 \mathrm{H}$ benzyl, $\mathrm{J}=8.1 \mathrm{~Hz}), 7.57-7.62(\mathrm{~m}, 2 \mathrm{H}$ acridine), 7.8-7.85 ( $\mathrm{m}, 2 \mathrm{H}$ acridine), 7.96 (d, $2 \mathrm{H}$ acridine, $\mathrm{J}=7.8 \mathrm{~Hz}), 8.29$ (d, 2H Benzyl J=8.1 Hz), 7.57-7.62 (m, $2 \mathrm{H}$ acridine), $7.96(\mathrm{~d}, 2 \mathrm{H}$ acridine, $\mathrm{J}=7.8 \mathrm{~Hz}), 8.29(\mathrm{~d}, 2 \mathrm{H}$ acridine, $\mathrm{J}=8.7 \mathrm{~Hz}$ ), 8.69 (s, 1H, CH). Ms, m/z (\%):410 (M 98.1), 411 (29.3), 305 (24.2), 235 (52.9), 190 (9), 105 (100), 77 (8.3).

The standard solutions of LPSF/AC 04 at concentrations ranging from 0.3 to $2.0 \mu \mathrm{g} \cdot \mathrm{mL}^{-1}$ were prepared in methanol from a stock solution $\left(100 \mu \mathrm{g} \cdot \mathrm{mL}^{-1}\right)$. Standard solutions were prepared in triplicate to validate the analytical method.

\section{Analytical method validation}

The validation of the UV spectrophotometric analytical method was carried out based on parameters including linearity, limits of detection and quantification, specificity, precision, accuracy and robustness (ANVISA, 2003; ICH, 1995A; ICH, 1996B). All assays were performed at $25^{\circ} \mathrm{C}$ except for the robustness assay, where samples were also stored at $4{ }^{\circ} \mathrm{C}$ and $37^{\circ} \mathrm{C}$ before analysis.

Initially, UV spectra of LPSF/AC04 at different concentrations $\left(0.3,0.5,1,1.5\right.$ and $\left.2 \mu \mathrm{g} . \mathrm{mL}^{-1}\right)$ were obtained to determine the wavelength of greatest absorptivity.

\section{Specificity}

The specificity of the method was evaluated by comparing the UV spectra of blank samples (HP- $\beta-\mathrm{CD}$ and unloaded liposomes) against LPSF/AC04 standard solution. The analysis of LPSF/AC04-loaded liposomes and LPSF/AC04:HP- $\beta$-CD inclusion complex scanning was also performed from 225 to $340 \mathrm{~nm}$ and checked for changes in absorbance at the respective wavelengths.

\section{Linearity}

The linearity of the proposed method was verified by preparing three different standard solutions of LPSF/AC04 $\left(0.3,0.5,1.0,1.5\right.$ and $\left.2.0 \mu \mathrm{g} \cdot \mathrm{mL}^{-1}\right)$, analyzed in triplicate, to plot nine derived analytical curves. The linearity of the analytical curve was evaluated by linear regression analysis using the least squares method and analysis of variance (ANOVA).

\section{Limits of detection and quantification}

Limits of detection (LOD) and quantification (LOQ) were estimated according to ICH guidelines (ICH, 1995A; ICH, 1995B). Limit of detection was calculated by: $L O D=3.3(\mathrm{\sigma} / \mathrm{S})$, and limit of quantification was calculated by: $L O Q=10(\sigma / S)$, where $\sigma$ is the standard deviation of the response of the blank and $S$ is the slope of the analytical curve.

\section{Accuracy}

The accuracy of the method was determined by the recovery of a known amount of LPSF/AC04 added to samples of unloaded liposomes and HP- $\beta-C D$. Briefly, to determine the accuracy of the proposed method, different levels of drug concentrations were used: lower concentration $\left(0.5 \mu \mathrm{g} \cdot \mathrm{mL}^{-1}\right)$, intermediate concentration $\left(1.0 \mu \mathrm{g} \cdot \mathrm{mL}^{-1}\right)$ and higher concentration $\left(1.5 \mu \mathrm{g} \cdot \mathrm{mL}^{-1}\right)$. A known aliquot of LPSF/AC04 stock solution was transferred to a $10 \mathrm{~mL}$ volumetric flask containing unloaded liposomes or an accurately weighed amount of HP- $\beta-C D$ equivalent to the quantity in the LPSF/AC04:HP- $\beta$-CD inclusion complex (Section 2.6.1) and filled to volume with methanol. A 1:10 dilution in methanol of the sample was then performed.

The samples were prepared in triplicate and analyzed by the proposed method. The relative standard deviation and LPSF/AC04 recovery percentage were employed to evaluate the accuracy of the method by applying equation 1 . The paired $t$-test at a $95 \%$ level of significance was performed to compare the mean absorbance of the samples.

Recovery $(\%)=\frac{\text { theoretical drug concentration }}{\text { found drug concentration }}$ Eq. 1 


\section{Precision}

Inter-day, intra-day and inter-analyst variations were studied to determine repeatability and intermediate precision of the proposed analytical method. Intermediate precision was determined by analyzing three different levels of LPSF/AC04 concentrations at 0.5, 1.0, $1.5 \mu \mathrm{g} . \mathrm{mL}^{-1}$. Different solutions were prepared in triplicate by two different analysts at two different times during one day and analyzed for intra-day variations. The same procedure was followed for two different days to study inter-day and inter-analyst variations (ANVISA, 2003). The percentage relative standard deviation (\%RSD) of the predicted concentrations from the regression equation was taken as the measure of precision. The paired $t$-test at a $95 \%$ level of significance was performed to compare the mean absorbance of the samples.

\section{Robustness}

The robustness of the method was evaluated by changing the solvent suppliers and the temperature of the LPSF/AC0 4 samples $\left(1.5 \mu \mathrm{g} . \mathrm{mL}^{1}\right)$ at 4,25 and $37^{\circ} \mathrm{C}$. The samples were previously prepared and transferred to sealed tubes and refrigerated at $4{ }^{\circ} \mathrm{C}$ or maintained at different temperatures $\left(25\right.$ and $\left.37^{\circ} \mathrm{C}\right)$ for $24 \mathrm{~h}$ prior to analysis. Assays were performed three times under the same conditions (ANVISA, 2003; Ulu, Elmali, 2010).

\section{Application of the method: determination of LPSF/AC04 from inclusion complex and liposomes}

\section{Preparation of LPSF/AC04:HP- $\beta-C D$ inclusion complex}

LPSF/AC-04:HP- $\beta$-CD complex was prepared using freeze-drying. First, stoichiometric amounts of HP- $\beta-C D$ and LPSF/AC04 were dissolved in purified water and the mixture stirred for $72 \mathrm{~h}$ at $25^{\circ} \mathrm{C}$, then frozen in liquid nitrogen and finally lyophilized at $4 \times 10^{-6}$ Bars for $72 \mathrm{~h}$.

\section{Preparation of LPSF/AC04 and LPSF/AC04:HP- $\beta-C D$ -} loaded liposomes

LPSF/AC0 4 and LPSF/AC04:HP- $\beta$-CD-loaded liposomes were prepared using the thin lipid film method (Mendonça et al., 2012). Drug entrapment efficiency was determined using ultrafiltration by the ultracentrifugation technique (Ultrafree ${ }^{\circledR}$ units, Millipore, USA). Samples of LPSF/AC0 4 and LPSF/AC04:HP- $\beta$-CD-loaded liposomes $(400 \mu \mathrm{L})$ were placed into the filtration unit and submitted to ultracentrifugation at $8,792 \mathrm{~g}$ for $1 \mathrm{~h}$. The samples were analyzed at $250 \mathrm{~nm}$ for determination of LPSF/AC0 4 content using a LPSF/AC04 analytical curve with concentrations ranging from 0.3 to $2.0 \mu \mathrm{g} \cdot \mathrm{mL}^{-1}$. All samples were prepared in triplicate. Data are expressed as percentage of total content of LPSF/AC04 entrapped in liposomes.

\section{RESULTS AND DISCUSSION}

\section{Analytical method validation}

The absorption spectra of the LPSF/AC04 in methanol were recorded at concentrations ranging from 0.3 to $2.0 \mu \mathrm{g} . \mathrm{mL}^{-1}$ (Figure 3). LPSF/AC0 4 was found to exhibit a maximum absorption peak $\left(\lambda_{\max }\right)$ at $250 \mathrm{~nm}$ with a molar absorptivity $(\varepsilon)$ of $7.60 \times 10^{4} \mathrm{~L} \cdot \mathrm{mol}^{-1} \cdot \mathrm{cm}^{-1}$. In addition, no interference from the solvent in LPSF/AC04 shoulder peaks near $\lambda_{\max }$ was verified. Methanol can thus be considered a suitable solvent for validating the proposed method, since it showed no interference in the analysis, thus supporting the reproducibility of the results.

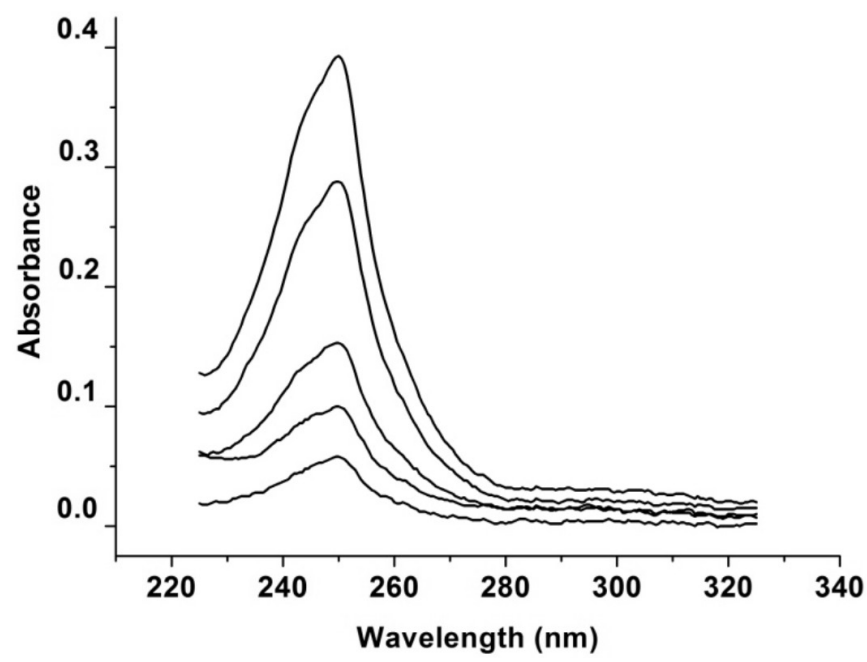

FIGURE 2 - Scanning UV spectra of LPSF/AC04 at concentrations of $0.3,0.5,1,1.5$ and $2 \mu \mathrm{g} \mathrm{mL}^{-1}$ in methanol.

\section{Specificity}

The method described was specific for the determination of LPSF/AC04 in inclusion complex and liposomes. A well-defined peak of LPSF/AC04 was observed at $250 \mathrm{~nm}$. In addition, the absorption spectrum of blank samples (HP- $\beta$-CD without LPSF/AC04) and unloaded liposomes showed no peak at the specific wavelength of LPSF/AC04 (Figure 3). The absorption peak of LPSF/AC04 at $250 \mathrm{~nm}$ was unchanged in the presence of the constituents of the liposomal formulation and HP- $\beta-C D$, thereby demonstrating the specificity of the method. 

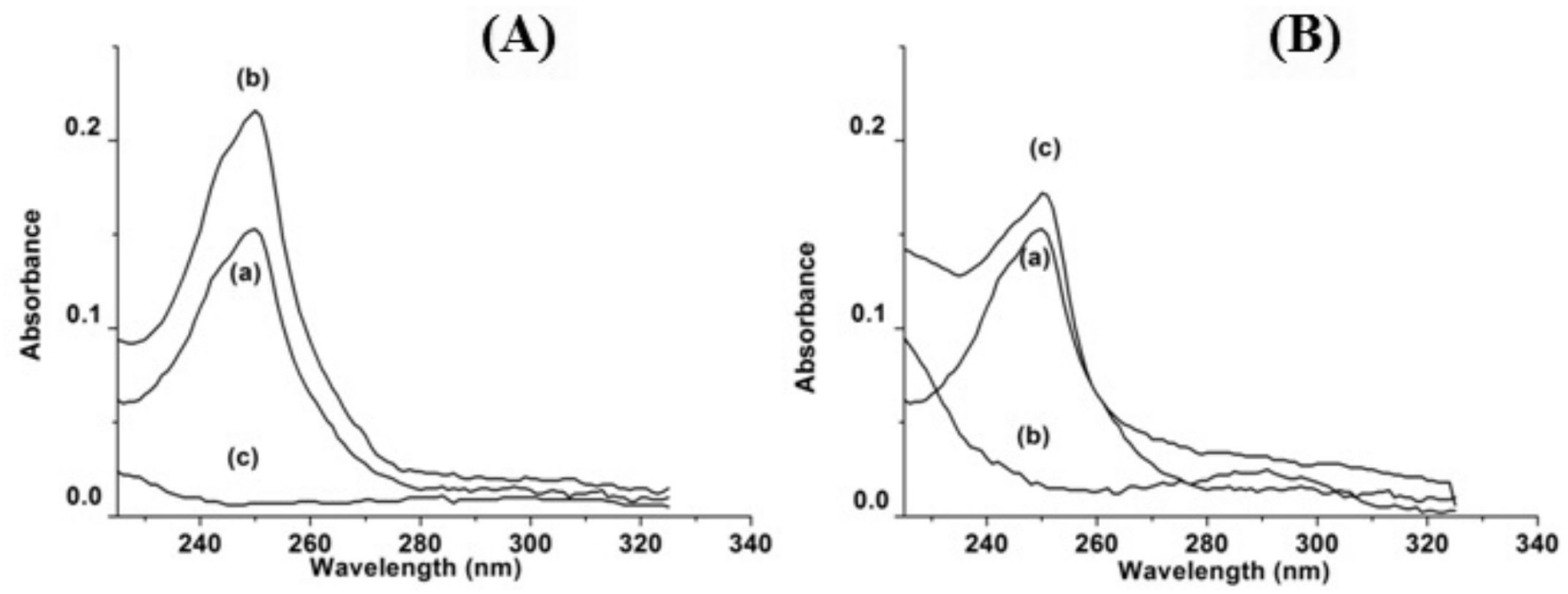

FIGURE 3 - Scanning UV spectra of: (A) LPSF/AC04 $\left(1 \mu \mathrm{g} \cdot \mathrm{mL}^{-1}\right)$ (a); LPSF/AC04:HP- $\beta$-CD inclusion complexes (b) and HP- $\beta$-CD (c), (B) LPSF/AC04 (1 $\left.\mu \mathrm{g} \cdot \mathrm{mL}^{-1}\right)$ (a); unloaded liposomes (b) and LPSF/AC04-loaded liposomes $\left.2 \mu \mathrm{g} \cdot \mathrm{mL}^{-1}\right)$ (c) diluted in methanol.

\section{Linearity}

Absorbance at $\lambda_{\max }=250 \mathrm{~nm}$ and concentrations of $\mathrm{LPSF} / \mathrm{AC} 04$ ranging from 0.3 to $2.0 \mu \mathrm{g} \cdot \mathrm{mL}^{-1}$ presented a linear relationship (Table I), and the regression analysis data are summarized in Table II. The analytical curves were fitted by least squares treatment to give the following mean regression equation: Absorbance $=0.18068 \times[\mathrm{LPSF} /$ AC04, $\mu$ g.mL $\left.\mathrm{mL}^{-1}\right]+0.00348\left(\mathrm{r}^{2}=0.9995, \mathrm{n}=9\right)$ (Figure 4).

TABLE I - Experimental results of validation parameters

\begin{tabular}{cc}
\hline $\begin{array}{c}\text { Concentration } \\
\left(\boldsymbol{\mu g} . \mathbf{~ m L}^{-1}\right)\end{array}$ & $\begin{array}{c}\text { Mean absorbance } \\
( \pm \mathbf{S D})^{\mathbf{a}}\end{array}$ \\
\hline 0.3 & $0.056 \pm 0.002$ \\
0.5 & $0.095 \pm 0.004$ \\
1.0 & $0.186 \pm 0.007$ \\
1.5 & $0.271 \pm 0.004$ \\
2.0 & $0.365 \pm 0.007$ \\
\hline
\end{tabular}

${ }^{a}$ Values represent the mean of three analytical curves.

\section{Limits of detection and quantification}

The limit of detection (LOD) and the limit of quantification (LOQ) of LPSF/AC04 were $0.047 \mu \mathrm{g} . \mathrm{mL}^{-1}$ and $0.143 \mu \mathrm{g} . \mathrm{mL}^{-1}$, respectively. These results showed that the method was sensitive even at low concentrations of LPSF/AC04.

\section{Accuracy}

The accuracy of the procedure was determined by recovery tests of known quantities of LPSF/AC04 (0.5,
TABLE II - Optical characteristics of LPSF/AC04, statistical data of regression equations and validation parameters

\section{LPSF/AC04}

Validation

Parameters

\section{Optical characteristics}

Molar absorptivity, $\varepsilon\left(\mathrm{L} \cdot \mathrm{mol}^{-1} \cdot \mathrm{cm}^{-1}\right)$

$7.60 \times 10^{4}$

\section{Regression analysis}

Slope (S.E. $)^{2}$

$0.18068\left(2.09 \times 10^{-3}\right)$

Intercept (S.E. ${ }^{\mathrm{a}}$ )

Regression coefficient $\left(\mathrm{r}^{2}\right)$

$0.00348\left(2.58 \times 10^{-3}\right)$

0.99946

\section{Validation parameters}

Measurement wavelength (nm) $\quad 250$

Linear range $\left(\mu \mathrm{g} \cdot \mathrm{mL}^{-1}\right) \quad 0.3-2.0$

Limit of detection, $\operatorname{LOD}\left(\mu \mathrm{g} . \mathrm{mL}^{-1}\right) \quad 0.047$

Limit of quantification, LOQ $\left(\mu \mathrm{g} \cdot \mathrm{mL}^{-1}\right) \quad 0.143$

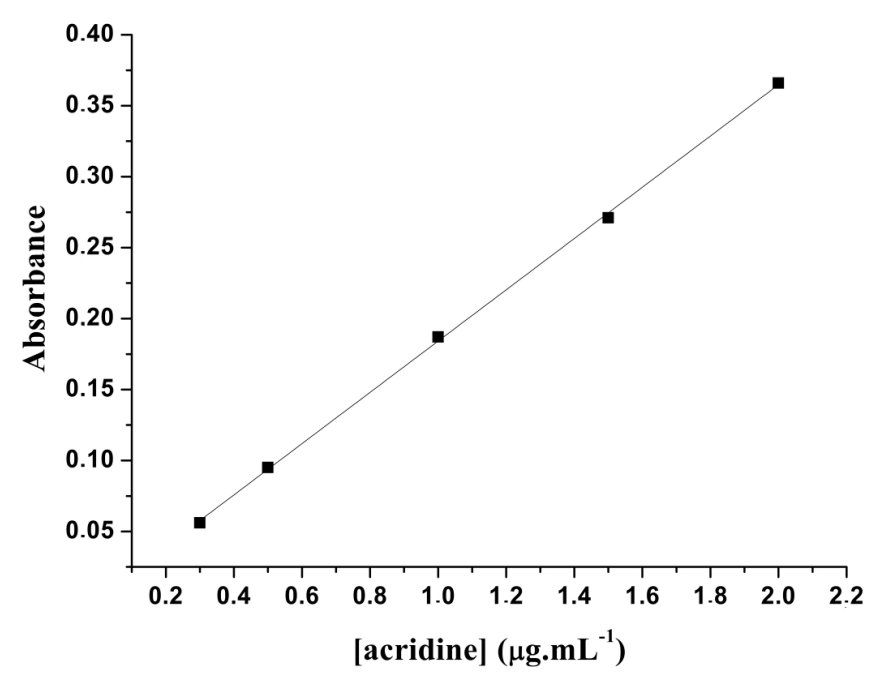

FIGURE 4 - Analytical curve or Plot linearity. 
1.0 and $\left.1.5 \mu \mathrm{g} . \mathrm{mL}^{-1}\right)$ spiked in unloaded liposomes and HP- $\beta$-CD. LPSF/AC04 recoveries ranged from 101.06 $\pm 2.09 \%$ to $100.71 \pm 1.35 \%$ for HP- $\beta-C D$ (Table III) and $99.36 \pm 0.67 \%$ to $101.51 \pm 1.91 \%$ (Table IV) for liposome. The mean LPSF/AC04 recovery values were close to $100 \%$, and their low standard deviation values evidence the high accuracy of the analytical method. These results reveal that small changes in the drug concentration in the solutions can be accurately determined by the proposed analytical method.

\section{Precision}

Repeatability (RSD\%) ranged from 4.20 to 4.34 (\%) for three levels of LPSF/AC04 concentrations (Table V). The results of repeatability (intra-day precision) of the method indicated the precision under the same operating conditions over a short period of time. Inter-day precision expresses within-laboratory variations on different days by different analysts (ANVISA, 2003). In the precision study, RSD\% values were less than $5 \%$ in all cases and

TABLE III - Recovery of LPSF/AC04 in HP- $\beta$-CD matrix to evaluate the accuracy of the UV method

\begin{tabular}{lccccc}
\hline Added & $\begin{array}{c}\text { Found } \\
( \pm \text { S.D. })^{\mathbf{a}}\end{array}$ & $\begin{array}{c}\text { RSD } \\
(\mathbf{\%})\end{array}$ & $\begin{array}{c}\text { Mean recovery } \% \\
( \pm \text { S.D. })^{\mathbf{a}}\end{array}$ & \multicolumn{2}{c}{ t values } \\
\hline 0.5 & $0.505 \pm 0.010$ & 1.01 & $101.06 \pm 2.09$ & 0.47 & $\mathbf{t}_{\text {cal }}{ }^{\mathbf{b}}$ \\
1.0 & $1.012 \pm 0.028$ & 1.10 & $101.26 \pm 2.87$ & 0.52 & 4.30 \\
1.5 & $1.510 \pm 0.020$ & 0.67 & $100.71 \pm 1.35$ & 0.45 & 4.30 \\
\hline
\end{tabular}

${ }^{\mathrm{a}}$ Values represent the mean of nine measurements. ${ }^{\mathrm{b}} t_{\text {cal }}$ is the calculated value and $t_{\text {crit }}$ is the theoretical value based on the paired $t$-test at the level of significance of $p=0.05$.

TABLE IV - Recovery of LPSF/AC04 in liposomes to assess the accuracy of the proposed method

\begin{tabular}{lccccc}
\hline Added & $\begin{array}{c}\text { Found } \\
( \pm \text { S.D. })^{\mathbf{a}}\end{array}$ & $\begin{array}{c}\text { RSD } \\
(\mathbf{\%})\end{array}$ & $\begin{array}{c}\text { Mean recovery\% } \\
( \pm \text { S.D. })^{\mathbf{a}}\end{array}$ & \multicolumn{2}{c}{ t values } \\
\hline 0.5 & $0.502 \pm 0.006$ & 1.02 & $100.56 \pm 1.33$ & 0.53 & $\mathbf{t}_{\text {cal }}^{\text {b }}$ \\
1.0 & $1.015 \pm 0.022$ & 0.76 & $101.51 \pm 1.91$ & 0.40 & 4.30 \\
1.5 & $1.490 \pm 0.010$ & 0.49 & $99.36 \pm 0.67$ & 0.24 & 4.30 \\
\hline
\end{tabular}

${ }^{\mathrm{a}}$ Values represent the mean of nine measurements. ${ }^{\mathrm{b}} t_{\text {cal }}$ is the calculated value and $t_{\text {crit }}$ is the theoretical value based on the paired $t$-test at the level of significance of $p=0.05$.

TABLE V - Precision of proposed analytical method

\begin{tabular}{|c|c|c|c|c|c|}
\hline Precision & $\begin{array}{c}\text { [LPSF/AC04] } \\
\text { Added } \\
\left(\mu \mathrm{g} . \mathrm{mL}^{-1}\right)\end{array}$ & $\begin{array}{c}\text { [LPSF/AC04] } \\
\text { Found } \pm \text { S.D. } \\
\left(\mu \text { g.mL }{ }^{-1}\right)\end{array}$ & $\begin{array}{c}\text { R.S.D. } \\
\text { (\%) }\end{array}$ & $t_{\text {cal }}^{a}$ & $t_{\text {tab }}$ \\
\hline \multicolumn{6}{|l|}{ Inter-day } \\
\hline \multirow{3}{*}{$\begin{array}{l}\text { Same analyst } \\
\text { (days } 1 \text { and 2) }\end{array}$} & 0.5 & $0.494 \pm 0.02$ & 4.36 & 0.57 & 2.57 \\
\hline & 1.0 & $1.011 \pm 0.02$ & 2.50 & 0.31 & 2.57 \\
\hline & 1.5 & $1.496 \pm 0.02$ & 1.52 & 0.73 & 2.57 \\
\hline \multicolumn{6}{|l|}{ Inter-day } \\
\hline \multirow{3}{*}{$\begin{array}{l}\text { Analysts } 1 \text { and } 2 \\
\text { (days } 1 \text { and } 2 \text { ) }\end{array}$} & 0.5 & $0.498 \pm 0.02$ & 4.01 & 0.83 & 2.57 \\
\hline & 1.0 & $1.008 \pm 0.05$ & 4.78 & 0.68 & 2.57 \\
\hline & 1.5 & $1.529 \pm 0.07$ & 4.46 & 0.33 & 2.57 \\
\hline \multicolumn{6}{|l|}{ Intra-day } \\
\hline \multirow{3}{*}{$\begin{array}{l}\text { Different tests } \\
\text { (same analyst; day 1) }\end{array}$} & 0.5 & $0.494 \pm 0.02$ & 4.20 & 0.57 & 2.57 \\
\hline & 1.0 & $1.019 \pm 0.04$ & 4.34 & 0.32 & 2.57 \\
\hline & 1.5 & $1.534 \pm 0.06$ & 4.20 & 0.25 & 2.57 \\
\hline
\end{tabular}

${ }^{\mathrm{a}} t_{\mathrm{cal}}$ is the calculated value; ${ }^{\mathrm{b}} t_{\mathrm{tab}}$ is the theoretical value based on the paired $t$-test at the level of significance of $p=0.05(\mathrm{n}=6)$. 
TABLE VI - Robustness of the UV method using different solvent suppliers and temperatures of LPSF/AC04 samples

\begin{tabular}{lcccc}
\hline \multirow{2}{*}{ Parameters } & \multicolumn{4}{c}{ LPSF/AC04 $\left(\mu \mathbf{g ~ m L}^{-1}\right)$} \\
\cline { 2 - 5 } & Added & Found \pm S.D. & RSD (\%) & $\mathbf{t}_{\text {cal }}{ }^{\text {a }}$ \\
\hline Solvents 1 & 1.5 & $1.49 \pm 0.01$ & 0.93 & 0.62 \\
Solvents 2 & 1.5 & $1.57 \pm 0.01$ & 1.07 & 0.01 \\
$\mathbf{4}^{\circ} \mathbf{C}$ & 1.5 & $1.50 \pm 0.06$ & 4.13 & 0.84 \\
$\mathbf{2 5}^{\circ} \mathbf{C}$ & 1.5 & $1.54 \pm 0.01$ & 1.07 & 0.05 \\
$\mathbf{3 7}^{\circ} \mathbf{C}$ & 1.5 & $1.52 \pm 0.00$ & 2.33 & 0.42 \\
\hline
\end{tabular}

${ }^{a} t_{\text {cal }}$ is the calculated value. The theoretical value $\mathrm{t}_{\text {crit }} 4.30$ is based on the paired $t$-test at the level of significance of $p=0.05(\mathrm{n}=3)$.

were well within the acceptable range, indicating that the method has good repeatability and inter-day precision (ANVISA, 2003).

\section{Robustness}

The analytical method proved to be robust (Table VI), since no statistically significant differences (Student's $t$-test) were found when samples were subjected to temperature variations and diluted in solvents from different manufacturers. The satisfactory recovery of LPSF/AC-04 from liposomes (>99\%) stored at different temperatures confirmed that the molar absorptivity of LPSF/AC04 is not dependent on temperature.

\section{Application of the method: determination of LPSF/AC04 in inclusion complex and liposomes}

The encapsulation efficiencies of LPSF/AC04 and LPSF/AC04:HP- $\beta-C D$ in liposomes were 99.02 $\pm 1.56 \%$ and $93.57 \pm 0.37 \%$, respectively. In the literature, the quantification of hydrophobic molecules in inclusion complexes and liposomes have been performed successfully using the proposed spectrophotometry method (Siqueira-Moura et al., 2008; Cavalcanti et al., 2012; Lapenda et al., 2012).

The high encapsulation efficiency of LPSF/AC04 and LPSF/AC04:HP- $\beta$-CD from liposomes indicated the effectiveness of the proposed method in the quantification of LPSF/AC04.

\section{CONCLUSION}

The proposed spectrophotometric analytical method for determination of LPSF/AC04 proved simple, rapid, accurate, precise and low-cost. The method was applied to quantify the LPSF/AC04 in inclusion complex as well in liposomes and can therefore be used for routine analysis.

\section{ACKNOWLEDGMENTS}

The authors wish to thank the Conselho Nacional de Desenvolvimento Científico e Tecnológico (CNPq) for grant \# 474071/2007-3. The first author is also grateful to the Coordenação de Aperfeiçoamento de Pessoal de Nível Superior (CAPES) for a scholarship grant.

\section{REFERENCES}

AGÊNCIA NACIONAL DE VIGILÂNCIA SANITÁRIA. ANVISA. R E, no 899 de 29 de maio de 2003. Guia para validação de métodos analíticos e bioanalíticos. Diário Oficial da União Poder Executivo, Brasilia, 02 jun. 2003. Available at: $<$ http://portal.anvisa.gov.br $>$. Acessed on: 05 Sept. 2013.

AL OMARI, A. A.; AL OMARI, M .M.; BADWAN, A. A.; ALSOU'OD, K. A. Effect of cyclodextrins on the solubility and stability of candesartan cilexetil in solution and solid state. J. Pharm. Biomed., v.54, p.503-509, 2011.

BONSE, S.; SANTELLI-ROUVIER, C.; BARBEJ.; KRAUTH-SIEGEL, R. L. Inhibition of Trypanosomacruzi trypanothione reductase by acridines: kinetic studies and structure-activity relationships. J. Med. Chem., v.42, p.5448-5454, 1999.

CAVALCANTI, I. M. F.; MENDONÇA, E. A. M.; LIRA, M. C. B.; HONRATO, S. B.; CAMARA, C. A.; AMORIM, R. V. S.; FILHO, J. M.; RABELLO, M. M.; HERNANDEZ, M. Z.; AYALA, A. P.; SANTOS-MAGALHÃES, N. S. The encapsulation of $\beta$-lapachone in 2-hydroxypropyl$\beta$-cyclodextrin inclusion complex into liposomes: a physicochemical evaluation and molecular modeling approach. Eur. J. Pharm. Sci., v.44, p.332-340, 2011. 
CORREIA, I.; BEZZENINE, N.; RONZANI, N.; PLATZER, N.; BELOEIL, J-C.; DOAN, B-T. Study of inclusion complexes of acridine with $\beta$-and (2,6-dio-methyl)- $\beta$-cyclodextrin by use of solubility diagrams and NMR spectroscopy. J. Phys. Org. Chem., v.15, p.647-659, 2002.

DARWISH, I. A.; ABDINE, H. H.; AMER, S. M.; ALRAYES, L. I. Spectrophotometric study for the reaction between fluvoxamine and 1,2-naphthoquinone-4sulphonate: Kinetic, mechanism and use for determination of fluvoxamine in its dosage forms. Spectrochim. Acta A, v.72, p.897-902, 2009.

DE LIMA, M.C.A.; LINS, G.S.; PITTA, I.R. Acridine derivatives with antitumoral activity. Patent number WO/2007/109871A2.PCT/BR2007/000074.2007.04.10, 23 Mar. 2007, 04 Out. 2007. Federal University of Pernambuco, UFPE, Brasil.

DENNY, W. A. Acridine derivatives as chemotherapeutic agents. Curr. Med. Chem., v.9, p.1655-1665, 2002.

GIRAULT, S.; GRELLIER, P.; BERECIBAR, A.; MAES,L.; MOURAY, E.; LEMIERE, P.; DEBREU, M.A.; DAVIOUDCHARVET E.; SERGHERAERT, C. Antimalarial, antitrypanosomal, and antileishmanial activities and cytotoxicity of Bis(9-amino-6-chloro-2-methoxyacridines): Influence of the linker. J. Med. Chem., v.43, p.2646-54, 2000 .

GOODELL, J. R.; MADHOK, A. A.; HIASA, H.; FERGUSON, D. M.. Synthesis and evaluation of acridine-andacridonebased anti-herpes agents with topoisomerase activity. Bioorg. Med. Chem., v.14, p.5467-5480, 2006. .

GOODELL, J. R.; OUGOLKOV, A. V.; HIASA, H.; KAUR, H.; REMMEL, R.; BILLADEU, D. D.;FERGUNSON, D. M. Acridine-based agents with topoisomerase II activity inhibit pancreatic cancer cell proliferation and induce apoptosis. $J$. Med. Chem., v.51, p.179-182, 2008.

INTERNATIONAL CONFERENCE ON HARMONISATION. ICH. Validation of analytical procedures: definitions and terminology. Q2A (CPMP/ICH/381/95). 1995A. Available at: <http://www.ich.org/products/guidelines/quality/article/ quality-guidelines.html>. Accessed on: 28 Jan. 2013.
INTERNATIONAL CONFERENCE ON HARMONISATION. ICH. Validation of analytical procedures: methodology. Q2B (CPMP/ICH/281/95), 1996B. Available at: ttp://www.ich. org/products/guidelines/quality/article/qualityguidelines. html>. Accessed on: 28 Jan. 2013.

LAPENDA, T. L. S.; MORAIS, W. A.; LIRA, M. C. B.; MACIEL, M. A. M.; SANTOS-MAGALHÃES, N. S. Validation of a UV spectrophotometric method for determining trans-dehydrocrotonin in inclusion complexes with hydroxypropyl- $\beta$-cyclodextrin. Lat. Am. J. Pharm., v.31, p.1-7, 2012.

LOFTSSON, T.; HREINSDÓTTIR, D.; MÁSSON, M. Evaluation of cyclodextrin solubilization of drugs. Int. J. Pharm., v.302, p.18-28, 2005.

LOFTSSON, T.; DUCHÊNE, D. Cyclodextrins and their pharmaceutical applications. Int. J. Pharm., v.329, p.1-11, 2007.

MENDONÇA, E. A. M.; LIRA, M.C.B.; RABELLO, M. M.; CAVALCANTI, I. M. F.; GALDINO, S. L.; PITTA, I. R.; LIMA, M. C. A.; PITTA, M. G. R.; MARCELO, M. Z.; SANTOS-MAGALHÃES, N. S. Enhanced Antiproliferative Activity of the New Anticancer Candidate LPSF/AC04 in Cyclodextrin Inclusion Complexes Encapsulated into Liposomes. AAPS Pharm. Sci. Tech., v.13, p.1355-1366, 2012.

MISHUR, R. J.; GRIFFIN, M. E.; BATTLE, C. H.; SHAN, B.; JAYAWICKRAMRAJAH, J. Molecular recognition and enhancement of aqueous solubility and bioactivity of CD437 by $\beta$-cyclodextrin. Bioorg. Med. Chem. Lett., v.21, p.857-860, 2011.

MOURÃO, R. H.; SILVA, T. G.; SOARES, A. L.; VIEIRA, E. S.; SANTOS, J. N.; LIMA, M. C. A.; LIMA, V. L. M.; GALDINO, S. L.; BARBE, J.; PITTA, I. R. Synthesis and biological activity of novel acridinylidene and benzylidene thiazolidinediones. Eur. J. Med. Chem., v.40, p.1129-1133, 2005.

PIGATTO, M C.; LIMA, M. C. A.; GALDINO, S. L.; PITTA, I. R.; VESSECCHI, R.; ASSIS, M. D.; SANTOS, J. S.; COSTA, T. D.; LOPES, N. P. Metabolism evaluation of the anticancer candidate $\mathrm{AC} 04$ by biomimetic oxidative model and rat liver microsomes. Eur. J. Med. Chem., v.46, p.4245-4251, 2011. 
SCHUETTE, J. M.; DOU, T. N.; DE LA PEÑA, A. M.; GREENE, K. L.; WILLIAMSON, C. K.; WARNER, I. M. Characterization of the $\beta$-cyclodextrin/acridine complex. $J$. Phys. Chem., v.95, p.4897-4902, 1991.

SIQUEIRA-MOURA, M. P.; LIRA, M. C. B.; SANTOSMAGALHÃES, N. S. Validação de método analítico espectrofotométrico UV para determinação de ácido úsnico em lipossomas. Braz. J. Pharm. Sci., v.44, p.621-628, 2008.
TORCHILIN, V. P. Multifunctional nanocarriers. Adv. Drug. Deliver. Rev., v.58, p.1532-1555, 2006.

ULU, S. T.; ELMALI, F. T. Spectrophotometric method for the determination, validation, spectroscopic and thermal analysis of diphenhydramine in pharmaceutical preparation. Spectrochim. Acta, v.77, p.324-329, 2010.

Received for publication on $04^{\text {th }}$ October 2013 Accepted for publication on $02^{\text {nd }}$ September 2014 
